\title{
RESUMO DE TESE
}

\section{ATIVIDADE ANTIPARASITÁRIA E IMUNOMODULADORA DO FATOR DE NECROSE TUMORAL ALFA NA MALÁRLA HUMANA}

Vários são os mecanismos envolvidos na defesa contra o plasmódio. Sabe-se que os monócitos e macrófagos possuem papel importante na eliminação das formas sanguíneas do plasmódio e que o fator de necrose tumoral alfa também participa dos mecanismos de eliminação do parasita.

Os objetivos do presente trabalho foram o de contribuir para o esclarecimento dos mecanismos pelos quais o FNT-alfa realiza sua ação efetora antiparasitária, bem como avaliar o papel desta citocina na depressão da resposta de linfócitos $T$ observada na malária

O papel antiparasitário do FNT-alfa foi avaliado por meio da verificação da sua influência sobre a fagocitose de eritrócitos parasitados pelo Plasmodium falciparum, por monócitos/macrófagos do sangue periférico de individuos normais. Foi verificada também a influência da citocina recombinante sobre a inibição do crescimento do Plasmodium falciparum por monócitos/macrófagos e linfócitos in vitro. A influência do FNT-alfa presente no soro de indivíduos com malária, sobre os monócitos/macrófagos na inibição do crescimento do Plasmodium falciparum in vitro, foi avaliada utilizando anticorpo policlonal anti-FNT-alfa. O papel imunomodulador do FNT-alfa foi avaliado por meio da influência da citocina, presente no soro dos indivíduos com malária, sobre a proliferação de linfócitos $T$ estimulada pela fitohemaglutinina, na presença ou na ausência do anticorpo policlonal anti-FNT-alfa.

O FNT-alfa recombinante humano aumentou a capacidade fagocitáiia dos monócitos/macrófagos para eritrócitos parasitados apenas na presença de anticorpos antiplasmódio, em base dose-dependente. O FNT-alfa recombinante também foi capaz de aumentar a inibição do crescimento do Plasmodium falciparum pelas célulaś mononucleares in vitro, possivelmente por estimular a liberação de substâncias tóxicas para o parasita, por monócitos/macrófagos. O FNT-alfa recombinante influenciou as interações entre monócitos/macrófagos e linfócitos, aumentando a capacitação destas células no processo de destruição do Plasmodium falciparum. Os soros dos indivíduos com malária apresentaram atividade antiparasitária que foi parcialmente reduzida pelo anticorpo policlonal anti-

Recebido para publicação em 02/12/94.

\section{ANTIPARASITIC ACTIVITY AND IMMUNOMODULATORY EFFECT OFTUMOUR NECROSIS FACTOR ALPHA IN HUMAN MALARIA}

Different mechanisms are involved in the defence of the host against plasmodia. It has been recognized that monocytes and macrophages play a role as an effector mechanism in malaria, and that tumour necrosis factor alpha (TNF-alpha) in some way also contributes to the elimination of the parasite.

The present investigation aimed at understanding the antiplasmodial effect of TNFalpha, and also at evaluating the role played by this cytokine on the depression of the immune response in malaria.

The antiplasmodial effect of TNF-alpha was assessed through: a) its interference on the phagocytosis of Plasmodium falciparum-infected erythrocytes by monocytes/macrophages obtained from the venous blood of non-infected individuals; b) the ability of recombinant TNFalpha to influence in vitro growth of Plasmodium falciparum in the presence of monocytes/macrophages and lymphocytes; c) the influence of the cytokine, present in the serum of infected individuals, on the inhibition of in vitro growth of Plasmodium falciparum by monocytes/macrophages, using an anti-TNFalpha serum. The immunomodulatory effect of TNF-alpha was evaluated through its interference on the proliferation of lymphocytes cultured with a T-cell mitogen, phytohaemagglutinin.

We showed that recombinant TNF-alpha increased the phagocytic capacity of monocytes/macrophages towards Plasmodium falciparum-infected erythrocytes, but exclusively in the presence of antiplasmodial antibodies, and in a dosis-dependent basis. This cytokine was also capable of increasing Plasmodium falciparum in vitro growth inhibition by monocytes/macrophages, possibly by enhacing the cytotoxic effects of these cells. Sera of malaria-infected individuals showed antiplasmodial activity, which was partially abolished by anti-TNF-alpha antiserum. These same sera, when added to cultures of normal lymphocytes caused inhibition of the mitogen- 
FNT-alfa, e também inibiram a proliferação dos linfócitos estimulados pela fitohemaglutinina. Esta inibição foi parcialmente revertida pelo anticorpo policlonal anti-FNT-alfa.

Concluímos que o FNT-alfa apresenta papel modulador das funções dos monócitos/macrófagos e dos linfócitos, e que o mesmo pode aumentar a atividade antiparasitária destas células. A produção descontrolada desta citocina na infecção malárica pode participar da imunodepressão que ocorre durante a infecção. induced proliferation of these cells. This inhibition was partially reversed by the anti-TNFalpha antiserum.

It was conclued that TNF-alpha increases the antiplasmodial effects of monocytes/macrophages, and when produced in excess, as happens during the infection, it may play a role in the depression of the immune response associated with acute malaria.

\section{Maria Imaculada Muniz Barboza Junqueira}

Tese apresentada à Faculdade de Ciências da Saúde da Universidade de Brasília para obtenção do Titulo de Doutor.

Brasillia, DF, Brasil, 1994. 